\title{
Porównanie właściwości mechanicznych powłok natryskiwanych plazmowo proszkowo i z zawiesin
}

\author{
Comparison of mechanical properties \\ of the plasma sprayed coatings by powder and suspension
}

\section{Streszczenie}

W artykule zestawiono dwie metody natryskiwania plazmowego (proszkowego oraz z zawiesin) oraz dokonano porównania wybranych właściwości mechanicznych. Materiałem na powłoki był tlenek cyrkonu stabilizowany tlenkiem itru. Powłoki zostały naniesione ze zbliżonymi parametrami. Wyznaczenie właściwości mechanicznych obejmowało: pomiary twardości instrumentalnej, określenie modułu sprężystości podłużnej, wyznaczenie odporności na kruche pękanie $\left(K_{\mathrm{Ic}}\right)$ oraz wykorzystanie metody IIT (ang. Interface Indentation Test) w celu określenia wrażliwości powłok do delaminacji. Otrzymane wyniki wykazały przewagę parametrów użytkowych powłok natryskanych z zawiesin.

Słowa kluczowe: natryskiwanie plazmowe; proszek; zawiesina; powłoka; test indentacji; odporność na kruche pękanie

\begin{abstract}
In this work the two methods of plasma spraying have been compiled (powder and suspension ones) and a comparison of selected mechanical properties was made. Feeding material was yttria stabilized zirconia. The coatings were obtained with similar parameters. The studies of mechanical properties included: hardness measurements by instrumented indentation tests, investigations of elastic modulus, calculation of fracture toughness $\left(\mathrm{K}_{\mathrm{Ic}}\right)$ and an ability of coatings delamination investigations by interface indentation test, IIT. Obtained results proved advantage of utility parameters of the coatings sprayed by suspension.
\end{abstract}

Keywords: plasma spraying; powder; suspension; coating; indentation test; fracture toughness

\begin{abstract}
Wstęp
Powłoki ceramiczne, które m.in. stosuje się jako odporne na zużycie ścierne, powinny charakteryzować się przede wszystkim wysoką twardością. Jednak w przypadku, gdy istotna jest również wysoka odporność na erozję, należy uwzględnić odporność na propagację pęknięć $[1,2]$. Podczas gdy pomiary twardości powłok są znormalizowane i ich metodologia od lat jest dobrze poznana, to wyznaczenie odporności na kruche pękanie jest kwestią złożoną [3]. Nie można bowiem przenieść metodologii z materiałów litych na układy dwuwarstwowe, tj. powłoka-podłoże.

W celu określenia odporności na kruche pękanie powłok zaproponowano różne metody, jednak najczęściej stosowaną jest tzw. Vickers Indentation Toughness, VIT [4], czyli wyznaczanie odporności na pękanie przy pomocy indentacji z wykorzystaniem wgłębnika Vickersa. Ponadto, w układach powłoka-podłoże bardzo istotną kwestią jest określenie skłonności do delaminacji, która również bazuje na zastosowaniu indentacji wgłębnikiem Vickersa $[5,6]$.
\end{abstract}

W prezentowanej pracy przeprowadzono badania wybranych właściwości mechanicznych, w tym wyznaczono oraz porównano ze sobą odporność na kruche pękanie ceramicznych powłok natryskanych plazmowo z proszku oraz z zawiesin.

\section{Materiały i metody}

Powłoki zostały naniesione przy pomocy palnika plazmowego SG-100 (Praxair) na podłoża stalowe X5CrNi18-10 (wg PN-EN ISO 10088 [7]), które wcześniej przygotowano poprzez obróbkę strumieniowo-ścierną. W obu przypadkach materiałem powłoki był tlenek cyrkonu stabilizowany tlenkiem itru (8\% wag.), YSZ (ang. Yttria Stabilized Zirconia). Jednak dla natryskiwania plazmowego proszkowego, PPS (ang. Powder Plasma Spraying) średnia wielkość cząsteczek proszku wynosiła $d_{50}=52 \mu \mathrm{m}$. Na potrzeby procesu natryskiwania plazmowego z zawiesin, SPS (ang. Suspension Plasma Spraying),

Mgr inż. Monika Michalak, dr inż. Leszek Łatka, dr inż. Paweł Sokołowski - Politechnika Wrocławska.

Autor korespondencyjny/Corresponding author. leszek.latka@pwr.edu.pl 
proszek został zmielony w młynie kulowym, a średnia wielkość cząsteczek proszku została zmniejszona do $\mathrm{d}_{50}=0,8 \mu \mathrm{m}$. Szczegóły dotyczące metody SPS można znaleźć np. w $[8,9]$. Parametry natryskiwania obu metod zestawiono w tablicy I. Po wytworzeniu powłok, próbki zostały przecięte oraz zainkludowane w żywicy, a następnie zgłady poddano szlifowaniu i polerowaniu.

Tablica I. Oznaczenie próbek oraz parametry natryskiwania Table I. Sample labelling and spraying parameters

\begin{tabular}{|c|c|c|c|c|}
\hline Próbka & $\begin{array}{c}\text { Moc elek- } \\
\text { tryczna, } \\
\text { kW }\end{array}$ & $\begin{array}{c}\text { Odległość } \\
\text { natryskiwa- } \\
\text { nia, mm }\end{array}$ & $\begin{array}{c}\text { Prędkość } \\
\text { palnika, } \\
\text { mm/s }\end{array}$ & $\begin{array}{c}\text { Wydatek } \\
\text { gazów } \\
\text { plazmo- } \\
\text { twórczych, } \\
\text { I/min }\end{array}$ \\
\hline PPS & 38 & 100 & \multirow{2}{*}{500} & $\begin{array}{c}\mathrm{Ar} / \mathrm{H}_{2} \\
=45 / 5\end{array}$ \\
\hline SPS & 40 & 50 & & \\
\hline
\end{tabular}

\section{Metoda mikroindentacji}

W metodzie mikroindentacji możliwe do określenia są twardość oraz moduł sprężystości podłużnej na podstawie analizy krzywej w układzie siła - zagłębienie penetratora (rys. 1). Jest to metodologia bardzo pomocna przy badaniach powłok. Najczęściej stosuje się wgłębnik Vickersa, choć można również używać wgłębnika Berkovicha. Metodyka określania wartości twardości oraz modułu Younga została podana przez Oliviera i Pharra [10]. Szczegóły dotyczące tej metodologii zostały opisane w [11].

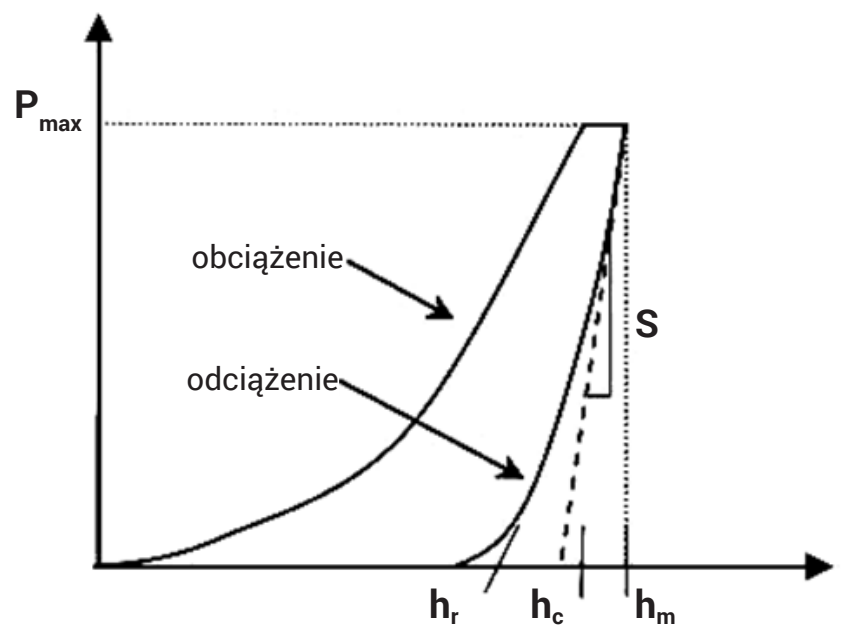

Rys. 1. Typowa krzywa w układzie siła-zagłębienie penetratora otrzymana podczas testu indentacji [12]

Fig. 1. Typical force-indentation depth curve obtained in an instrumented indentation test [12]

\section{Odporność na kruche pękanie}

Odporność na kruche pękanie jest bardzo istotnym parametrem dla materiałów ceramicznych oraz jednym z kryteriów ich przydatności w zastosowaniach inżynierskich. Zasadniczo jest ona określana przez podanie stałej materiałowej $\mathrm{K}_{\mathrm{lc}}$ - krytycznej wartości współczynnika koncentracji naprężeń [13]. Jej eksperymentalne wyznaczenie odbywa się wg normy PN-87 H-04335 [14] i polega na określeniu wytrzymałości na trójpunktowe zginanie belki z naciętym karbem o określonej geometrii (tzw. próbka SENB) [15].

W celu ujednolicenia wyników z takiej próby należy przeprowadzić badania na ok. 10 próbkach, których przygotowanie jest bardzo pracochłonne oraz kosztowne. Ponadto jest to metoda dobrze opisująca zachowania materiału litego a nie układu powłoka-podłoże. W związku z powyższym zaproponowano alternatywną metodę polegającą na bezpośrednim pomiarze długości spękań, które powstały w narożach odcisku powstałego po wgłębniku Vickersa (rys. 2). Oprócz długości spękania dokonuje się również pomiarów przekątnej wgłębienia. Jest to tzw. obserwacja Palmqvista, który zauważył, że długość spękań ma związek z wartością $K_{\mathrm{Ic}}$ [16]. W odróżnieniu od procedury opisanej w [17] jest to metoda o wiele mniej złożona i szybsza oraz niewymagająca przygotowywania próbek o dużych wymiarach. a)

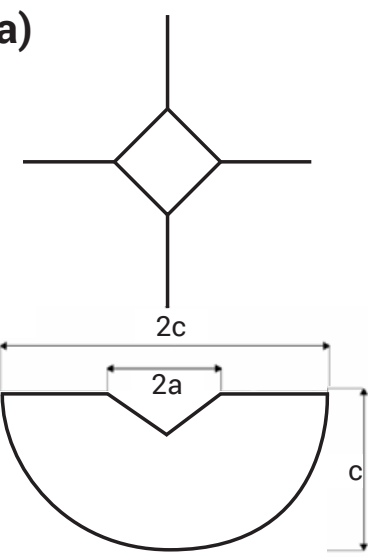

spękania środkowe b)

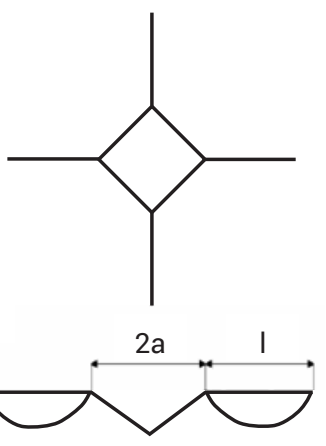

spękania Palmqvista
Rys. 2. Geometria i przekrój pionowy spękań wokół odcisku Vickersa: a) spękania środkowe, b) spękania Palmqvista [13]

Fig. 2. Geometry and vertical section of cracks around Vickers print: a) radial-median mode, b) Palmqvist mode [13]

Charakter spękania zależy przede wszystkim od rodzaju materiału oraz przyłożonego obciążenia. W przypadku materiałów mających niską wartość odporności na kruche pękanie obserwuje się radialne spękania wychodzące z naroży odcisku oraz spękania środkowe. Z kolei materiały mające wyższą odporność na kruche pękanie wykazują powstanie spękań Palmqvista w przypadku zastosowania mniejszych obciążeń. Natomiast dla większych są to spękania środkowe $[15,17,18]$. Najczęściej stosowanym sposobem identyfikacji rodzaju spękań jest kryterium uwzględniające stosunek długości l/a (rys. 2). Gdy wartość powyższej zależności mieści się w przedziale od 0,1 do 1,5 [13], wówczas wartość $K_{\text {Ic }}$ wyznacza się z modelu Niihary [19]:

$$
K_{I c}=0,018 \cdot H^{0,6} \cdot E^{0,4} \cdot 2 \cdot a \cdot l^{-0,5}
$$

gdzie:

$\mathrm{H}$ - twardość Vickersa [MPa],

E - moduł sprężystości Younga [MPa],

2a - przekątna wgłębienia [m],

I - średnia długość spękań [m].

Natomiast w przypadku gdy zależność l/a > 1,5 [13] stosuje się wzór Anstisa [20]:

$$
K_{I c}=0,016 \cdot\left(\frac{E}{H}\right)^{0,5} \cdot \frac{P}{c^{1,5}}
$$

gdzie:

$\mathrm{c}=\mathrm{a}+\mathrm{I}$ - całkowite spękanie [m],

$\mathrm{P}$ - obciążenie wgłębnika [N]. 
W przypadku, gdy wartość l/a > 1,0 istnieje duże prawdopodobieństwo, że spękania będą miały charakter mieszany. Wówczas należy określić wartość $\mathrm{K}_{\mathrm{Ic}}$ za pomocą obydwu wzorów i wybrać wyższą wartość. Nie generuje to znacznych błędów, ponieważ dla materiałów kruchych i tak są to wartości o $10 \div 15 \%$ niższe, niż te uzyskane w metodzie trójpunktowego zginania próbki z karbem (SENB) [15,18].

\section{Metoda Interfacial Indentation Test}

Metoda indentacji początkowo była stosowana jedynie dla kruchych materiałów litych. Jednak prostota zarówno przygotowania próbki, jak i przeprowadzenia badania spowodowała, że zaczęto jej używać również dla określenia odporności na kruche pękanie na styku powłoki z podłożem $[5,6,21]$. Zagłębianie ostrosłupa Vickersa na styku pomiędzy powłoką a podłożem skutkuje inicjacją oraz propagacją pęknięć w płaszczyźnie styku (rys. 3). Badania przeprowadza się poprzez pomiary długości powstałych pęknięć jako funkcji przyłożonego obciążenia, a następnie obliczenia pozornej odporności styku. Zauważono, żezależność pomiędzy długością pęknięcia a przyłożoną siłą jest liniowa (w podwójnej skali logarytmicznej), podobnie jak zależność pomiędzy połową przekątnej odcisku a obciążeniem. Przecięcie się tych dwóch prostych daje punkt o wartościach tzw. krytycznej siły $\left(P_{c}\right)$ powodującej najkrótsze pęknięcie $\left(c_{c}\right)$ na styku powłoka-podłoże [5].

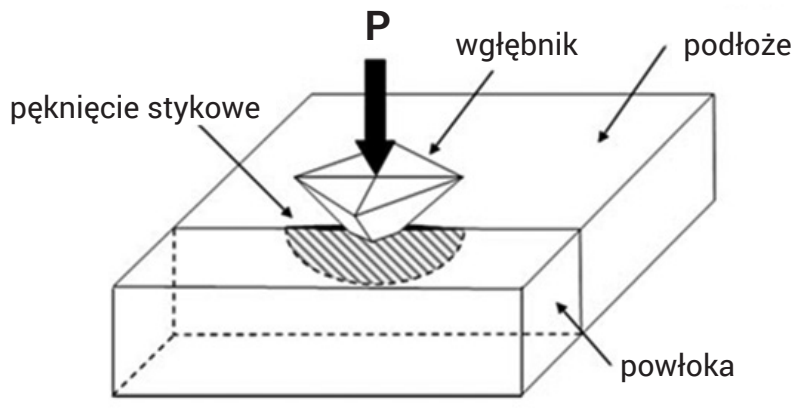

Rys. 3. Schemat badania metodą IIT (indentacji stykowej) [22] Fig. 3. Scheme of an interfacial indentation test [22]

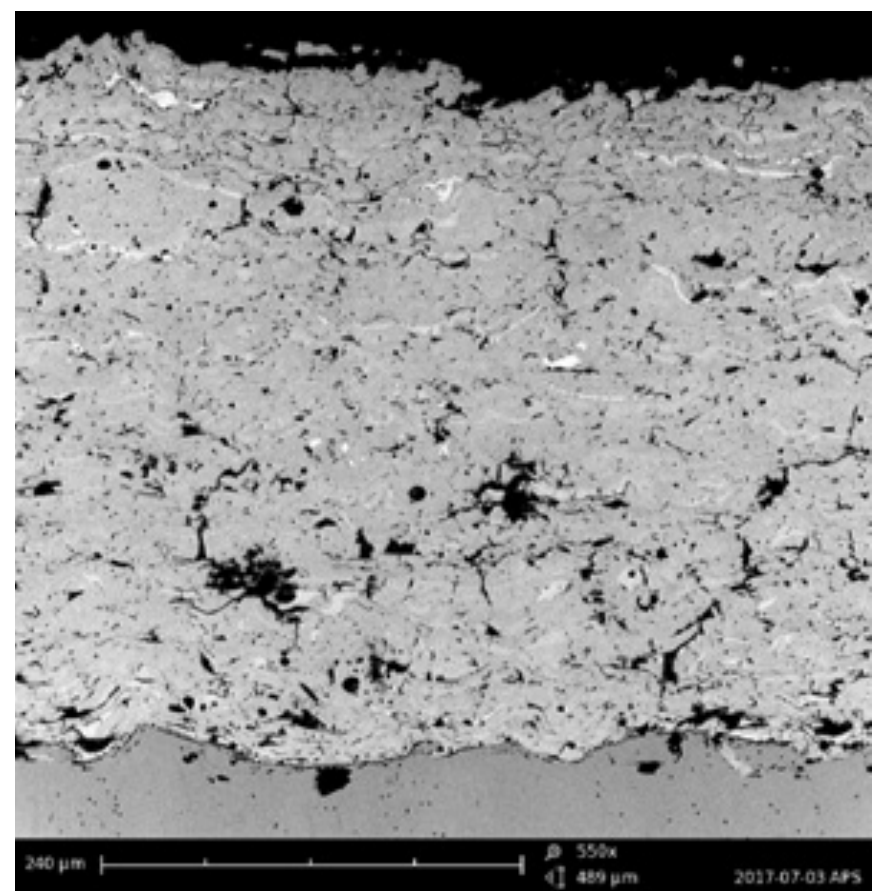

Bazując na licznych modelach odporności na kruche pękanie materiałów litych $w$ pracy $[4,5]$ zaproponowano zmodyfikowaną zależność oryginalnie wprowadzoną przez Anstis'a [20]:

E - moduł sprężystości [GPa],
$\mathrm{H}$ - twardość Vickersa [GPa].

$$
K_{c a}=0,0154 \cdot \frac{P_{c}}{c_{c}^{3 / 2}} \cdot\left(\frac{E}{H}\right)_{i}^{1 / 2}
$$

Z kolei relacja pomiędzy modułem sprężystości a twardością dla styku powłoka-podłoże przedstawia się następująco [5]:

$$
\left(\frac{E}{H}\right)_{i}^{1 / 2}=\frac{\left(\frac{E}{H}\right)_{S}^{1 / 2}}{1+\left(\frac{H_{S}}{H_{C}}\right)^{1 / 2}}+\frac{\left(\frac{E}{H}\right)_{C}^{1 / 2}}{1+\left(\frac{H_{C}}{H_{S}}\right)^{1 / 2}}
$$

gdzie indeksy i, s oraz c odnoszą się odpowiednio do styku, podłoża oraz powłoki.

\section{Wyniki i dyskusja}

Budowa powłok natryskanych plazmowo z proszków i zawiesin w dość istotny sposób różniła się między sobą. $\mathrm{Na}$ rysunku 4a można zauważyć charakterystyczną mikrostrukturę powłok dla procesu natryskiwania cieplnego. Występują pęknięcia, porowatość oraz pustki. Natomiast sama powłoka zbudowana jest z dobrze przetopionych i równolegle względem siebie osadzonych lamelli. Z kolei rysunek 4b przedstawia powłokę natryskaną z zawiesin. Widoczne są dłuższe pęknięcia spowodowane większym oddziaływaniem cieplnym (mniejsza odległość natryskiwania) oraz znacznie większa porowatość, choć wielkość pojedynczych porów jest zdecydowanie mniejsza niż dla powłok natryskiwanych proszkowo (PPS).

Porowatość powłok została określona na podstawie analizy obrazu z wykorzystaniem oprogramowania ImageJ. Wykonano po 10 zdjęć dla każdej powłoki za pomocą mikroskopu skaningowego, a następnie na ich podstawie określono wartości porowatości. Wyniosły one odpowiednio 9,0 \pm 0,6\% dla próbki PPS oraz $28,7 \pm 2,2 \%$ dla próbki SPS.

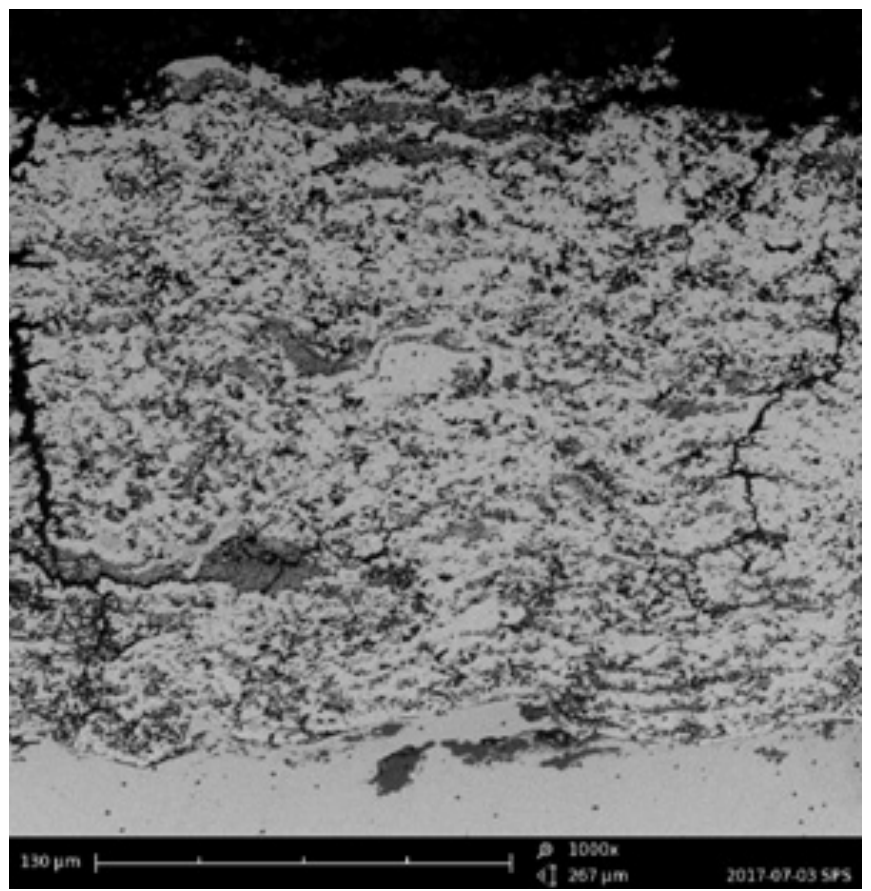

Rys. 4. Przekrój poprzeczny próbek natryskiwanych plazmowo: a) proszkowo (PPS), b) z zawiesin (SPS)

Fig. 4. Section of plasma sprayed samples: a) powder (PPS), b) suspension (SPS) 
Moduł sprężystości E oraz twardość H natryskanych powłok wyznaczono instrumentalną metodą wciskania wgłębnika zgodnie z normą PN-EN ISO 14577-4 [23] przy zastosowaniu penetratora Vickersa. Wykonano 10 pomiarów przy obciążeniu wynoszącym $1 \mathrm{~N}$. Wyniki zebrano w tablicy II. Jak można zauważyć, powłoka natryskana z zawiesin charakteryzuje się wyższą twardością oraz większym modułem Younga. Wynika to z rozdrobnienia ziaren wyjściowego proszku, co pociąga za sobą poprawę właściwości mechanicznych powłok otrzymanych metodą SPS w stosunku do tych natryskanych konwencjonalną techniką proszkową (PPS).

Tablica II. Średnie wartości twardości oraz modułu sprężystości natryskanych powłok

Table II. Average values of hardness and elastic modulus of sprayed coatings

\begin{tabular}{|c|c|c|}
\hline Próbka & HV, GPa & E, GPa \\
\hline PPS & $1,78 \pm 0,10$ & $58,63 \pm 1,94$ \\
\hline SPS & $2,15 \pm 0,12$ & $84,24 \pm 2,33$ \\
\hline
\end{tabular}

W celu określenia wartości współczynnika odporności na kruche pękania $\left(K_{\mathrm{Ic}}\right)$ dla powłok natryskanych plazmowo proszkowo oraz z zawiesin wykonano 10 odcisków w każdej próbce pod obciążeniem $\mathrm{P}=4,9 \mathrm{~N}$. Przykładowy odcisk w natryskanej powłoce przedstawia rysunek 5 . Następnie zmierzono długość spękań (c) oraz połowę odcisku (a) i obliczono parametr $\mathrm{K}_{\mathrm{lc}}$ wg modelu Niihary oraz Anstisa. Wartości zestawiono w tablicy III.

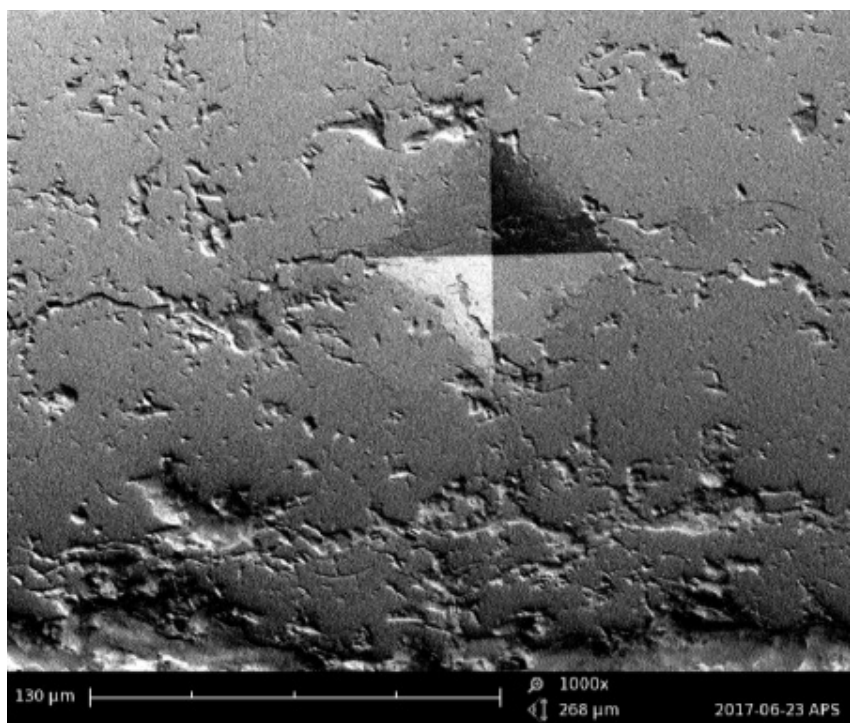

Rys. 5. Przykładowy odcisk Vickersa w powłoce PPS Fig. 5. Exemplary Vickers indent in the PPS coating

Tablica III. Porównanie wartości K $\mathrm{lc}$ natryskanych powłok wg modelu Niihary oraz Anstisa

Table III. Comparison of $\mathrm{K}_{\mathrm{lc}}$ values for sprayed coatings according to Niihara and Anstis models

\begin{tabular}{|c|c|c|}
\hline Próbka & $\begin{array}{c}\text { Model Niihary } \\
\mathbf{K}_{\mathrm{lc}}, \mathbf{M P a} / \mathbf{m}^{1 / 2}\end{array}$ & $\begin{array}{c}\text { Model Anstisa } \\
\mathbf{K}_{\mathrm{lc}}, \mathbf{M P a} / \mathbf{m}^{1 / 2}\end{array}$ \\
\hline PPS & $1,260 \pm 0,160$ & $1,666 \pm 0,301$ \\
\hline SPS & $1,463 \pm 0,193$ & $1,810 \pm 0,360$ \\
\hline
\end{tabular}

Wyższe wartości $K_{\mathrm{Ic}}$ dla powłoki SPS wynikają z nieco krótszych pęknięć oraz większej wartości ilorazu E/H, który opisuje pole naprężeń szczątkowych.

W toku rozwoju mechaniki pękania oraz stosowania indentacji z wgłębnikiem Vickersa opracowano ponad 20 modeli uwzględniających różne typy spękań. W prezentowanej pracy spękanie miały charakter środkowy i radialny. Dla tego typu spękań najczęściej wykorzystywane modele w celu określenia wartości $\mathrm{K}_{\mathrm{Ic}}$, oprócz modelu Anstis'a to: Niihary-Moreny-Hasselman'a (N-M-H), Lauginer'a oraz Casselas'a [24]. Różnią się one między sobą wartością współczynnika charakteryzującego pole naprężeń szczątkowych wokół odcisku Vickersa, czyli stałą kalibracyjną $\xi$ oraz różnych wartości wykładnika ilorazu E/H [25]. Wartości $\mathrm{K}_{\mathrm{lc}}$ wyznaczone wg najczęściej stosowanych zależności zestawiono na rysunku 6.

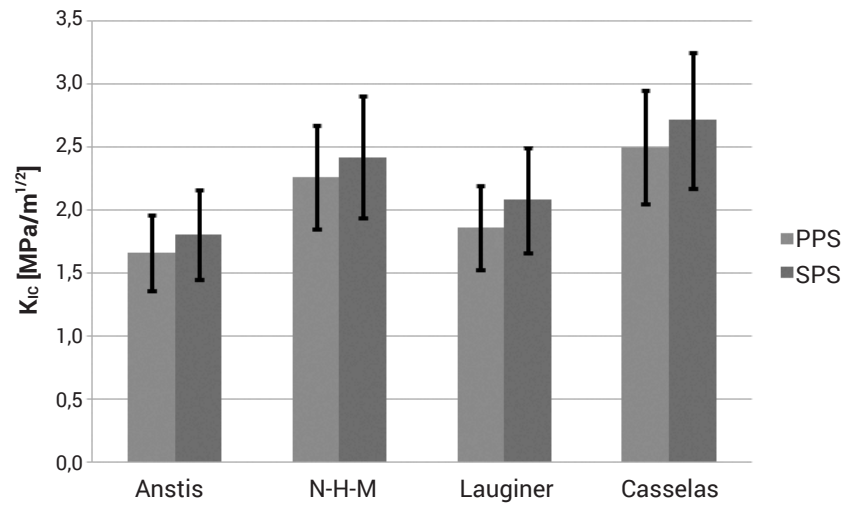

Rys. 6. Porównanie wyników dla różnych modeli określenia wartości $\mathrm{K}_{\mathrm{Ic}}$

Fig. 6. Comparison of the results for different models to define $\mathrm{K}_{\mathrm{Ic}}$ value

Miarą skłonności do delaminacji powłoki od podłoża w metodzie IIT jest również wyznaczenie wartości $K_{\mathrm{lc}}$, na podstawie zależności (3) i (4), jednak w tym celu należy określić tzw. krytyczną wartość siły $\left(\mathrm{P}_{\mathrm{c}}\right)$ oraz krytyczną wielkość pęknięcia $\left(\mathrm{c}_{\mathrm{c}}\right)$. Na rysunku 7 zamieszczono wyniki pomiarów długości pęknięć oraz połowy przekątnej odcisku w funkcji siły dla powłoki SPS. Następnie wyznaczono wartości $K_{\mathrm{lc}}$ dla obu powłok. Wyniosły one odpowiednio: 1,874 MPa/m $1 / 2$ dla próbki SPS oraz $1,195 \mathrm{MPa} / \mathrm{m}^{1 / 2}$ dla próbki PPS. Wynika to z krótszych pęknięć stykowych oraz nieco mniejszych odcisków powstałych w próbce SPS.

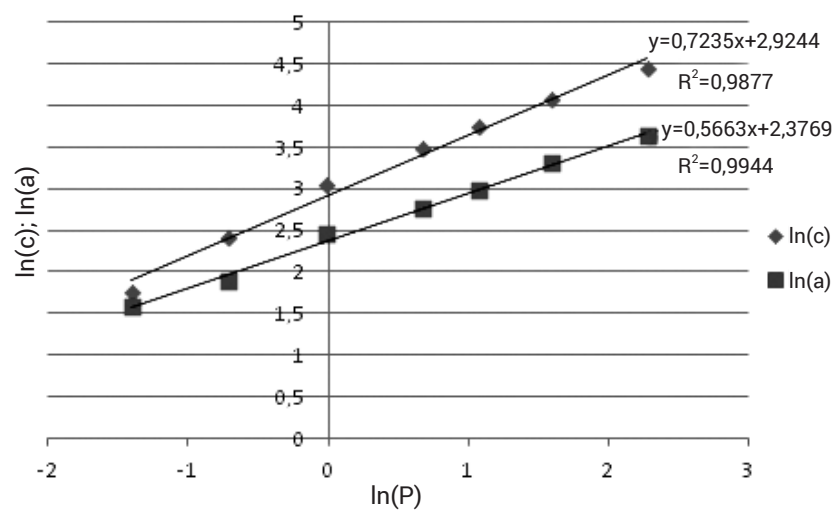

Rys. 7. Długość pęknięcia stykowego w funkcji przyłożonego obciążenia dla powłoki SPS

Fig. 7. Interface crack length as a function of applied load for SPS coating 


\section{Wnioski}

Przeprowadzone badania wybranych właściwości mechanicznych powłok ceramicznych natryskanych plazmowo wykazały, że:

- powłoki natryskane plazmowo z zawiesin (SPS) charakteryzowały się znacznie większą porowatością niż te natryskane plazmowo z proszków (PPS);

- powłoki natryskane metodą SPS pomimo ponad trzykrotnie większej porowatości charakteryzowały się większą wartością modułu Younga oraz wyższą twardością;

- wykorzystanie metodologii stosującej propagację pęknięcia od naroży odcisku Vickersa przyniosło porównywalne wartości;

- zauważono większą tendencję do powstawania spękań środkowych i radialnych niż Palmqvista;

- niezależnie od użytego modelu lepszą odpornością na kruche pękanie charakteryzowały się powłoki natryskane metodą SPS.

Ponadto, w próbie określenia skłonności do delaminacji powłoki (próba IIT), udowodniono mniejszą skłonność do rozwarstwiania próbki SPS (większa wartość $\mathrm{K}_{\mathrm{lc}}$ ). Można to tłumaczyć rozdrobnioną strukturą w tej powłoce oraz znacznie mniejszym rozmiarem porów (tzw. mikroporowatość).

\section{Przeprowadzone badania były finansowane przez Narodowe Centrum Nauki, projekt Sonata (UMO/2013/11/D/ST8/03400)}

\section{Literatura}

[1] Erickson L.C., Hawthorne H.M., Troczyński T.: Correlations between microstructural parameters, micromechanical properties and wear resistance of plasma sprayed ceramic coatings, Wear, vol. 250, 2001, pp. 569-575.

[2] Holmberg K., Matthews A.: Coatings tribology, Amsterdam, Elsevier, 1998.

[3] Houdkova S., Kasparova M.: Experimental study of indentation fracture toughness in HVOF sprayed hardmetal coatings, Engineering Fracture Mechanics, vol. 110, 2013, pp. 468-476.

[4] Chicot D., Duarte G., Tricoteaux A., Jorgowski B., Leriche A., Lasage J.: Vickers indentation fracture (VIF) modeling to analyze multi-cracking toughness of titania, alumina and zirconia plasma sprayed coatings, Materials Science Engineering A, vol. 527, 2009, pp. 65-76.

[5] Chicot D., Demarecaux P., Lesage J.: Apparent interface toughness of substrate and coating couples from indentation test, Thin Solid Films, vol. 283, 1996, pp. 151-157.

[6] Demarecaux P., Chicot D., Lesage J.: Interface indentation test for the determination of adhesive properties of thermal sprayed coatings, Journal of Materials Science Letters, vol. 15 (16), 1996, pp. 1377-1380.

[7] PN-EN ISO 10088-1:2014-12: Stale odporne na korozję - Część 1: Wykaz stali odpornych na korozję.

[8] Sokołowski P., Łatka L., Ambroziak A.: Badania mikrostruktury oraz wybranych właściwości powłok stabilizowanego tlenku cyrkonu wytwarzanych metodą natryskiwania plazmowego z zawiesin, Przegląd Spawalnictwa, vol. 86 (6), 2014, s. 48-54.

[9] Sokołowski P., Łatka L., Kozerski S.: Nowe możliwości wytwarzania powłokowych barier cieplnych metodą natryskiwania plazmowego z zawiesin, Przegląd Spawalnictwa, vol. 87 (3), 2015, s. 40-47.

[10] Olivier W.C., Pharr G.M.: An improved technique for determining hardness and elastic modulus using load and displacement sensing indentation experiments, Journal of Materials Research, vol. 7, 1992, pp. 1564-1583.

[11] Łatka L., Kozerski S., Pawłowski L., Chicot D.: Właściwości mechaniczne powłok hydroksyapatytu natryskiwanych plazmowo z zawiesin, Przegląd Spawalnictwa, vol. 84 (9), 2012, s. 73-78.

[12] Chicot D., Tricoteaux A.: Mechanical Properties of Ceramics by Indentation: Principle and Applications, in: Ceramic Materials, ed. W. Wunderlich, pp. 115-153.
[13] Pędzich Z., Piekarczyk J., Stobieralski L., Szutkowska M., Walat E.: Twardość Vickersa i odporność na kruche pękanie wybranych kompozytów ceramicznych, Kompozyty, vol. 3 (7), 2003, s. 296-300.

[14] PN-87 H-04335: Metoda badania odporności na pękanie w płaskim stanie odkształcenia, 1987.

[15] Pampuch R.: Materiały ceramiczne, Warszawa, PWN, 1988.

[16] Palmqvist S.: Occurence of crack formation during Vickers indentation as a measure of the toughness of hard metals, Arch. Eisenhuttenwes., vol. 33 (6), 1962, pp. 629-633.

[17] Blicharski M.: Inżynieria materiałowa, Warszawa, WNT, 2014.

[18] Munz D., Felt T.: Ceramicy: mechanical properties, failure behaviour, materials selection, Berlin, Heidelberg, New York, Springer Yerlag, 1999.

[19] Niihara K.: A fracture mechanics analysis of indentation-induced Palmqvist crack in ceramics, Journal of Materials Science Letters, vol. 2, 1983, pp. 221-223.

[20] Anstis G.R., Chantikul P., Lawn B.R., Marshall D.B.: A critical evaluation of indentation techniques for measuring fracture toughness: I, Direct crack measurements, Journal of the American Ceramic Society, vol. 64 (9), 1981, pp. 533-538.

[21] Lesage J., Chicot D.: Models for hardness and adhesion of coatings, Surface Engineering, vol. 15 (6), 1999, pp. 447-453.

[22] Yamazaki Y., Arai M., Miyashita Y., Waki H., Suzuki M.: Determination of interfacial fracture toughness of thermal spray coatings by indentation, Journal of Thermal Spray Technology, vol. 22 (8), 2013, pp. 1358-1365.

[23] PN-EN ISO 14577-4:2017-02: Metale - Instrumentalna próba wciskania wgłębnika do określania twardości i innych własności materiałów - Cześć 4: Metoda badania metalowych i niemetalowych powłok.

[24] Fabijanic T.A., Coric D., Musa M.S., Sakoman M.: Vickers indentation fracture toughness of near-nano and nanostructured WC-Co cemented carbides, Metals, vol. 143 (7), 2017 (www.mdpi.com/journal/metals).

[25] Boniecki M.: Wyznaczanie odporności na kruche pękanie ceramiki korundowej i korundowo-cyrkonowej metodą wprowadzania kontrolowanych pęknięć wstępnych wgłębnikiem Vickersa, Materiały Elektroniczne, vol. 22 (3), 1994, s. 34-51 